\title{
Purification of the used palm oil by adsorption
}

\author{
Bronisław Buczek, Wojciech Chwiałkowski \\ Cracow University of Economics, Department of General Chemistry, Faculty of Commodity Science, 30-033 Kraków, \\ ul. Sienkiewicza 5, Poland, e-mail: bbuczek@agh.edu.pl
}

\begin{abstract}
The components of fresh vegetable oils are mainly non-polar. During frying of food, complex and multistage reactions occur in the oil, which produce various polar compounds. Active carbons are characterized by small contents of polar functional groups, which are responsible for adsorbing such polar compounds. Effective purification of the used frying oils must involve the removal of the polar substances. To improve the quality of the used palm oil, an active carbon oxidized by a hydrogen peroxide treatment was used. Such a carbonaceous adsorbent improves the quality of the oil used for frying food by purifying it from colour substances, lipid hydrolysis products, oxidation products and total polar compounds.
\end{abstract}

Keywords: purification of used frying oil, active carbon, adsorption.

\section{INTRODUCTION}

Frying in deep fat is one of the most popular methods of preparing food, because of specific sensory values such as the flavour and the smell of the fried food, as well as an easy and fast way of preparing basic meals. Usually, in order to serve French chips or some other snacks, households and commercial food processors use vegetable fats. Oils are sources of polyenic fatty acids, which are indispensable for the normal functioning of the human body. As vegetable oils are unstable products and, when used for frying food undergo various transformations easily, one should not often consume fried food, especially fried in the oil of low quality.

Compounds of fresh vegetable oil, in the presence of oxygen, light, moisture and also at higher temperatures, undergo a complex series of changes and reactions during frying. Changes in the oils lead to the deterioration of their smell and taste, and to the formation of various chemical compounds (free radicals, peroxides, polymerisation and hydrolysis products, low molecular compounds and conjugated dienes, the products of the decomposition of hydroperoxides, hydrolysis of triglycerides and polymerisation). They are often very harmful and cause a decrease in the quality and the structural properties of the oil, and also accelerate its breakdown. The substances, which then form have a more or less chemical polar character.

In order to stop the progressive deterioration, some operation is required. The simplest solution is a frequent exchange of the used frying oil for a new one, however this generates the economical and ecological problems.

The purification of the used frying oils with adsorbents may improve the quality of the oils as well as of the fried food. The recovery of the used oil could be achieved by removing the undesirable oxidised, polar, colour substances and polymers. Various adsorbents could be used: mineral ${ }^{1,2}$ and carbonaceous ${ }^{3-5}$. The first group is more popular because of their polar surface character, which helps to adsorb polar compounds most effectively. Unfortunately, mineral adsorbents such as magnesium silicate cause utilization problems.

Active carbon adsorption might be an alternative purification procedure, but some additional processing is required. Active carbons have large surface areas and extended microporous structures, but are characterised by small contents of polar groups. The purification of the used frying oils needs to remove the products of their degradation and such systems do not succeed. The oxidation of active carbon leads to the modification of its surface to a more polar one. Concentrated mineral acids, e.g. sulphuric and nitric, and hydrogen peroxide $e^{6,7}$ are usually used as oxidation agents in the liquid phase. An oxidation process causes a change in the nature of the surface as well as in the texture of the carbonaceous adsorbent.

The objective of this study was the removal of degradation and oxidation products from palm oil used for frying potato chips, by its adsorption on the oxidised commercially produced active carbon.

\section{EXPERIMENTAL PROCEDURES}

\section{Materials \\ OP - fresh hydrogenated palm oil - Master Frit - Unigra'Spa, Italy. \\ OPR - hydrogenated palm oil - used for frying French chips in the fryer $\left(20 \mathrm{dm}^{3}\right)$ at the temperature of $180 \div 186^{\circ} \mathrm{C}$ for 3 days, about $100 \mathrm{~kg}$ chips were prepared, \\ ARP - oxidised active carbon - obtained from active car- bon AR, produced by ZEW Racibórz - (currently Carbon Racibórz Sp. z o.o. Poland) by the hydrogen peroxide oxida- tion.}

\section{Oxidation of active carbon}

Dry active carbon AR was treated with a $30 \%$ solution of hydrogen peroxide. For $25 \mathrm{~g}$ of active carbon $552 \mathrm{~cm}^{3}$ of solution was provided, and then the mixture was mixed for 2 hours. After the oxidation process, the suspension was decanted and the adsorbent was washed in the distillated water to achieve the $\mathrm{pH}$ level of about 4 . The so-obtained carbon ARP was next dried at the temperature of $120^{\circ} \mathrm{C}$ for 5 hours.

\section{Analysis of the porous structure of active carbon}

Porous structure was analysed on the basis of low-temperature nitrogen adsorption at the temperature of $77.5 \mathrm{~K}$ in the relative pressure range $\mathrm{p} / \mathrm{p}_{0}=0.0001-0.999$. The parameters of the microporous structure: micropores volume $\left(\mathrm{W}_{0}\right)$ and the characteristic adsorption energy $\left(\mathrm{E}_{0}\right)$ according to the Dubinin-Radushkevich equation ${ }^{8}$ were derived from these data. The mesopores surface area $\left(\mathrm{S}_{\mathrm{mes}}\right)$ was calculated from the Dollimore-Heal ${ }^{9}$ and the surface area $\left(\mathrm{S}_{\mathrm{BET}}\right)$ from the Brunauer-Emmett-Teller equations ${ }^{10}$ The Dubinin-Sierpinsky equation was used ${ }^{\mathbf{1 1}}$ in evaluating from the water sorption isotherm $\left(a_{0}\right)-$ the number of adsorption centres among 
Table 1. The properties and parameters of the porous structure of active carbons

\begin{tabular}{|l|c|c|c|c|}
\hline Parameter & Symbol & Unit & AR & ARP \\
\hline Micropores volume & $\mathrm{W}_{0}$ & $\mathrm{~cm}^{3} / \mathrm{g}$ & 0.423 & 0.372 \\
\hline $\begin{array}{l}\text { Characteristic } \\
\text { adsorption energy }\end{array}$ & $\mathrm{E}_{0}$ & $\mathrm{~kJ} / \mathrm{mol}$ & 18.5 & 21.1 \\
\hline $\begin{array}{l}\text { Mesopores surface } \\
\text { area }\end{array}$ & $\mathrm{S}_{\mathrm{me}}$ & $\mathrm{m}^{2} / \mathrm{g}$ & 207 & 180 \\
\hline Surface area & $\mathrm{S}_{\mathrm{BET}}$ & $\mathrm{m}^{2} / \mathrm{g}$ & 980 & 915 \\
\hline $\begin{array}{l}\text { Number of surface } \\
\text { group }\end{array}$ & $\mathrm{a}_{0}$ & $\mathrm{mmol} / \mathrm{g}$ & 1.54 & 5.32 \\
\hline
\end{tabular}

surface groups. The results of the calculations are presented in Table 1.

As a result of active carbon's oxidation, the carbonaceous material with a high value of characteristic adsorption energy $\left(\mathrm{E}_{0}\right)$ and more surface functional groups $\left(\mathrm{a}_{0}\right)$ was obtained. The oxidation process causes a slight degradation of the micro- and mesopore structure and of the surface area. However, the number of adsorption centres, which are responsible for the adsorption of polar compounds, was increased by more than three times (Table 1.)

\section{Purification of the used frying oil}

The OPRARP oil sample was obtained by the treatment of the used oil OPR with a modified active carbon ARP. The purification process was carried out in the weight ratio 15:1. The oil sample and the adsorbent were mixed and next heated for 30 minutes at the temperature of $70-80^{\circ} \mathrm{C}$. After this process, active carbon was separated from the oil through the filtration of hot suspension (about $60^{\circ} \mathrm{C}$ ), with the use of the strainer working under 2 atm. pressure.

\section{Analysis methods}

The oil purification process was aimed to remove the lipids degradation products, which were formed during the frying of French chips: mainly polar compounds, and to evaluate the efficiency of the applied adsorbent. The following features were adopted to estimate the changes of oil properties under the frying and purifying conditions:

- colour, $\pm 0.001^{\mathbf{1 2}}$,

- density $\rho 20$, (pycnometer method, $\pm 0,0004 \mathrm{~g} / \mathrm{cm}^{3}$ ),

- viscosity $\eta 40$, (Rheotest 3 apparatus, 60 s, 100 r.p.m, \pm 0,01 $\mathrm{Pa} \cdot \mathrm{s})$,

- iodine value IV, \pm 2.0 for IV $\in<50 ; 100>$ and \pm 3.5 for $\mathrm{IV} \in<100 ; 135>\mathbf{1 3}$,

- acid value $\mathrm{AV}, \pm 3 \%^{14}$,

- peroxide value $\mathrm{PV}, \pm 0.2 \mathrm{meq} \mathrm{O}_{2} / \mathrm{kg}^{15}$,

- anisidine value $\mathrm{AnV}, \pm 0.2^{\mathbf{1 6}}$

- total oxidation index Totox ${ }^{17}$,

- main fatty acids profiles determined by gas chromatography $\pm 3 \%$ for compounds above $5 \%$ and $\pm 0.2 \%$ for the compounds below $5 \% 18,19$,

- total polar compounds TPC, Oil Quality Tester - OIL METER FOM 200, $\pm 2 \%$.

The results of the measurements and calculations are shown in Table 2 and 3.

\section{RESULTS AND DISCUSSION}

During frying French chips in palm oil some unfavorable changes of the quality parameters occurred (Table 2.). The density, viscosity and the colour of the oil increased. The amount of the products of fatty acids hydrolysis - the free fatty acids' content (AV) was increased by almost 9 times. The
Table 2. The quality and the physicochemical properties of the oils under investigations

\begin{tabular}{|l|c|c|c|}
\hline Parameter & OP & OPR & OPRARP \\
\hline Colour & 50.7 & 88.7 & 39.0 \\
\hline$\rho^{20}, \mathrm{~g} / \mathrm{cm}^{3}$ & 0.911 & 0.915 & 0.917 \\
\hline$\eta^{40}, \mathrm{~Pa} \cdot \mathrm{s}$ & 0.037 & 0.047 & 0.046 \\
\hline $\mathrm{IV}, \mathrm{gl}_{2} / 100 \mathrm{~g}$ & 60.98 & 56.45 & 57.10 \\
\hline $\mathrm{AV}, \mathrm{mgKOH} / \mathrm{g}$ & 0.089 & 0.880 & 0.772 \\
\hline $\mathrm{PV}, \mathrm{milieq} . \mathrm{O}_{2} / \mathrm{kg}$ & 0.32 & 4.58 & 3.54 \\
\hline AnV & 1.10 & 70.20 & 59.80 \\
\hline Totox & 1.74 & 79.36 & 66.88 \\
\hline TPC, $\%$ & 12.6 & 29.2 & 23.0 \\
\hline
\end{tabular}

Table 3. The composition of fatty acid in the oil at various stages of purification and frying determined by gas chromatography [\% wt.]

\begin{tabular}{|l|c|c|c|}
\hline Fatty acids & OP & OPR & PRARP2 \\
\hline $\mathrm{C}_{12: 0}$ & 0.32 & 0.28 & 0.27 \\
\hline $\mathrm{C}_{14: 0}$ & 1.00 & 1.06 & 1.11 \\
\hline $\mathrm{C}_{16: 0}$ & 37.74 & 40.90 & 40.76 \\
\hline $\mathrm{C}_{16: 1 \text { (cis-9) }}$ & trace & 0.18 & 0.19 \\
\hline $\mathrm{C}_{18: 0}$ & 4.01 & 4.22 & 4.27 \\
\hline $\mathrm{C}_{18: 1 \text { (cis-9) }}$ & 44.50 & 42.64 & 42.63 \\
\hline $\mathrm{C}_{18: 1 \text { (trans-9) }}$ & - & 0.26 & 0.25 \\
\hline $\mathrm{C}_{18: 2 \text { (cis-9, 12) }}$ & 12.05 & 9.32 & 9.32 \\
\hline $\mathrm{C}_{18: 3 \text { (cis-6, 9, 12) }}$ & 0.45 & 0.41 & 0.38 \\
\hline $\mathrm{C}_{18: 3 \text { (cis-9, 12,15) }}$ & trace & 0.23 & 0.24 \\
\hline $\mathrm{C}_{20: 1 \text { (cis-11) }}$ & trace & 0.24 & 0.25 \\
\hline $\mathrm{C}_{20: 2 \text { (cis-11, 14) }}$ & - & 0.25 & 0.32 \\
\hline $\mathrm{C}_{20: 3 \text { (cis-8, 11, 14) }}$ & - & trace & trace \\
\hline $\mathrm{C}_{24: 0}$ & - & trace & trace \\
\hline $\mathrm{C}_{24: 1 \text { (cis-15) }}$ & - & - & - \\
\hline
\end{tabular}

"trace" - fatty acid's content: under the sensitivity threshold of the integrator $(<0,1 \%)$

amounts of the oil oxidation products (PV) and the secondary oxidation products $(\mathrm{AnV})$ increased by more than 13 and more than 62 times, respectively. In a similar way the frying process affects the total polar compounds content in oil (TPC) by about $130 \%$. The content of unsaturated substances (IV) was reduced by about $7.5 \%$ (Fig. 1.)

The purification process using oxidised active carbon leads to an improvement of most of the quality parameters. Acid, peroxide and anisidine values, as well as the total polar compounds content, were reduced by about 12 , nearly 23 , almost 15 and more than $21 \%$, respectively. The content of the unsaturated substances (IV) was increased by above $1 \%$. The total oxidation index, after the adsorption process, was reduced, by almost about $16 \%$. The biggest change occurred for the colour of the oil; purification by the oxidised active carbon treatment resulted in the parameter's improvement by more than $56 \%$ (Fig. 1.).

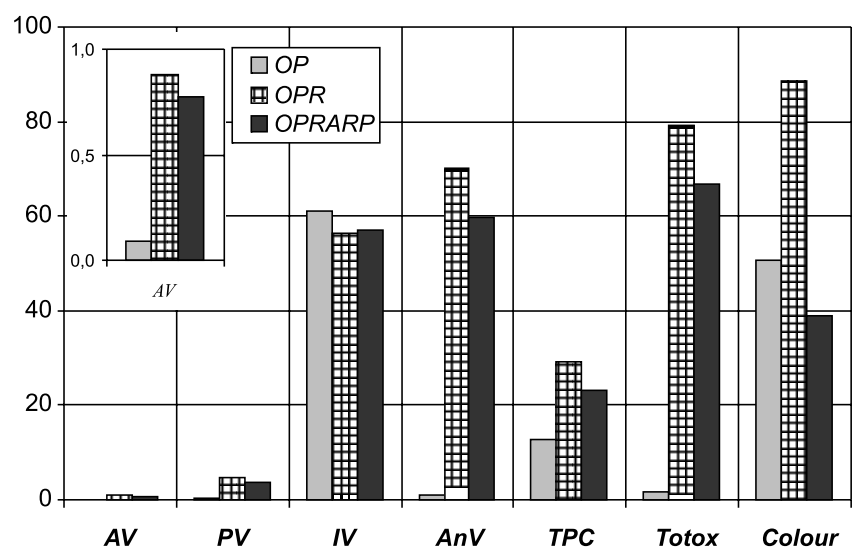

Figure 1. The quality parameters of the oil after each processing stage 
During thermal processing in oil, changes occur in fatty acids profiles (Table 3 and 4.). The content of the saturated fatty acids (SFA) grew by about $8 \%$. In that group, the amounts of palmitic $\left(\mathrm{C}_{16: 0}\right)$ and stearic acids $\left(\mathrm{C}_{18: 0}\right)$ increased by about 8 and $6.5 \%$, in relation to fresh oil, respectively.

The amounts of unsaturated fatty acids: mono - (MUFA) and polyunsaturated fatty acids (PUFA) decreased by almost 3 and almost $18 \%$, with reference to fresh medium (OP). The biggest changes in that group of fatty acids occurred in the contents of oleic $\left(\mathrm{C}_{18: 1 \text { (cis-9) }}\right)$ and linoleic $\left(\mathrm{C}_{18} 8_{2 \text { (cis-9, 12) }}\right)$ acids. The contents of these unsaturated fatty acids were decreased from 44.5 to $42.6 \%$ and from 12.1 to $9.3 \%$, respectively.

The adsorption process caused slight changes in the total content of saturated fatty acids (SFA) and polyunsaturated fatty acids (PUFA), whereas the content of monounsaturated fatty acids (MUFA) did not change. In fact, the purification process practically did not cause any improvement in the fatty acids content (Fig. 2, 3).

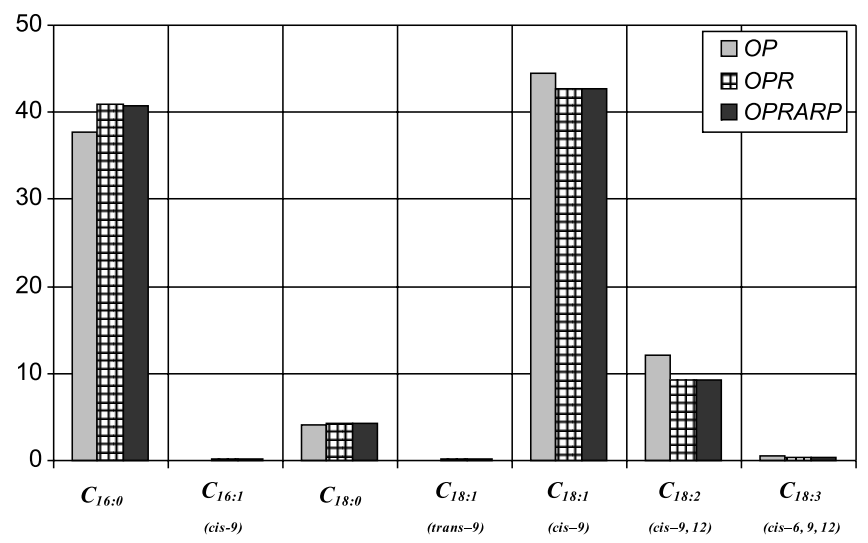

Figure 2. The main fatty acid contents in the oil

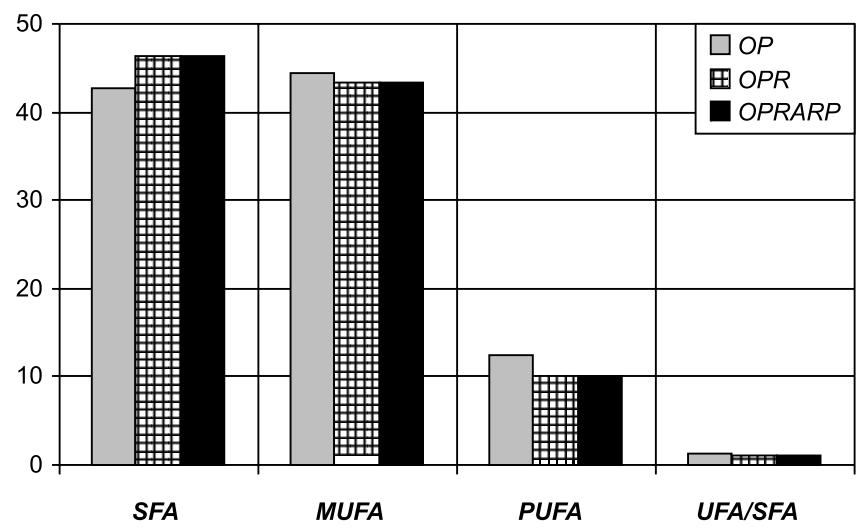

Figure 3. A group of fatty acids and the ratio of the amount of unsaturated fatty acids to the saturated fatty acids in the oil, (SFA - saturated fatty acids, MUFA - monounsaturated fatty acids, PUFA - polyunsaturated fatty acids, UFA - unsaturated fatty acids)

\section{SUMMARY}

The investigation indicates that active carbon, modified by perhydrol treatment, influenced the quality and the physicochemical properties of the used frying oil:

- active carbon with an oxidised surface character improves the properties of palm oil used for frying food - using relevant characteristic values,

- the ARP adsorbent purified the used frying oil from colour substances, lipid hydrolysis products, free fatty acids $(\mathrm{AV})$, primary and secondary oxidation products $(\mathrm{PV}, \mathrm{AnV})$ and total polar compounds (TPC),

- the obtained adsorbent did not reduce the fatty acids content effectively,

- to improve the quality of the purification of palm frying oil, a more efficient adsorbent, which stops unfavorable fatty acids, needs to be applied.

\section{SYMBOLS}

SFA

MUFA

PUFA

UFA

The authors are grateful to MNiSzW (N50801731/1220) for its financial support of this work.

\section{LITERATURE CITED}

1. Buczek, B. \& Chwiałkowski, W., Purification of Used Frying Oil by Treatment with Magnesium Silicate, 3rd Euro Fed Lipid Congress: Oils, Fats and Lipids in a Changing World, Edinburgh, Scotland, 2004, 142.

2. Cooke, B.S., Adsorbent Treatment of Frying Oils: Comemercial Frying Case Study, 4th Euro Fed Lipid Congress: Oils, Fats and Lipids for a Healthier Future, Madrid, Spain, 2006, 399.

3. Buczek, B. \& Chwiałkowski, W., Zastosowanie węgla aktywnego utlenionego nadtlenkiem wodoru do oczyszczania zużytego oleju smażalniczego, Mat. V Krajowej Konferencji Naukowo-Technicznej „Węgiel aktywny w ochronie środowiska i przemyśle", Częstochowa-Białwieża, 2006, 277 - 285.

4. Buczek, B. \& Chwiałkowski, W., Wpływ modyfikacji powierzchni węgla aktywnego na jego zdolność do oczyszczania oleju zużytego oleju smażalniczego, Żywność. Nauka. Technologia. Jakość, 2005, 4 (45) Supl., 85 - 91.

5. Chwiałkowski, W. \& Buczek, B., Odzyskiwanie zużytego oleju rzepakowego na modyfikowanym adsorbencie węglowym, Mat. I. Konferencji nt. Zielonej Chemii „EkoChemTech'03 Zielona Chemia”, Wrocław, 2003, 63.

6. Jankowska, H., Świątkowski, A., Starosin, L. \& Ławrinienko-Omiecynska, J., Adsorpcja jonów na węglu aktywnym, Wydawnictwo PWN Warszawa, 1991.

7. Sarbak, Z., Adsorpcja i adsorbenty - teoria i zastosowanie, WN UAM, Poznań, 2000.

8. Dubinnin, M.M., Adsorption properties and microporous structures of carbonaceous adsorbents, Carbon, 1987, 25, 593 - 597.

9. Dollimore, D. \& Heal. G.R., An improved method for the calculation of pore size distribution from adsorption data, J. Appl. Chem., 1964, 14, 109 - 113.

10. Lowell, S. \& Shields, J.E., Powder Surface Area and Porosity. Chapman and Hall, London, 1991.

11. Dubinnin, M.M., Water vapour adsorption and the microporous structures of carbonaceous adsorbent. Carbon, 1980, 18, 355 - 359.

12. PN-A-86934, Spektrofotometryczne oznaczanie barwy, 1995.

13. PN-ISO 6320, Oznaczanie liczby jodowej, 1995.

14. PN-EN-ISO 660, Oznaczanie liczby kwasowej i kwasowości, 2005.

15. PN-EN-ISO 3960, Oznaczanie liczby nadtlenkowej, 2005.

16. PN-EN-ISO 6885, Oznaczanie liczby anizydynowej, 1993.

17. PN-93-A-86926, Oznaczanie liczny anizydynowej oraz obliczanie wskaźnika oksydacji tłuszczu Totox, 1993.

18. PN-EN ISO 5508, Analiza estrów metylowych kwasów tłuszczowych metodą chromatografii gazowej, 1996.

19. PN-ISO 5509, Przygotowanie estrów metylowych, 1996. 